\title{
Linkage between emigration and export flows: The case of Bangladesh
}

\author{
Muhammad Shariat Ullaha ${ }^{2}$, Mohammad Thoufiqul Islam ${ }^{b}$ \\ aAssociate Professor, Department of Management, University of Dhaka, Dhaka 1000, Bangladesh. \\ b Associate Professor, Department of Management, University of Dhaka, Dhaka 1000, Bangladesh. \\ *Corresponding author's email address: shariat@du.ac.bd
}

\section{A R T I C L E I N F O}

Received: 22-01-2016

Accepted: 28-02-2016

Available online: 10-03-2016

Keywords:

Emigration; Export;

Complementary;

Gravity model;

Substitution.

\begin{abstract}
A B S T R A C T
This paper applies the well-known gravity model to empirically assess the linkage between emigration and export flows of a developing country. Econometric analysis of panel data unveils a significant substituting relationship between export flows from the source country and stock of emigrants to the destination country. This result not only contradicts with existing literature but also justifies manifold relationship between goods and manpower exports. Economic policy as well as foreign policy in Bangladesh must address this inherent relationship between export of goods and labor since emigration of unskilled labor largely depends on bilateral diplomatic relations whereas export patterns depend on comparative cost advantage.
\end{abstract}

JEL Classification:

F16; F22.

(C) 2016 The Authors. This is an open access article under the terms of the Creative Commons Attribution License 4.0, which allows use, distribution and reproduction in any medium, provided the original work is properly cited.

DOI: http://dx.doi.org/10.18533/jefs.v4i1.222

\subsection{Introduction}

Bangladesh is one of the leading exporters of manpower and it consistently strives to promote labor emigration since the country's balance of payments heavily relies on inward remittances. The World Bank (2011) estimated that there were 5.4 million Bangladeshi emigrants in the world that placed it as the second largest South Asian country of international labor supply and the sixth largest source of global immigration. Besides, Bangladesh has long been liberalizing its trade and investment policies with the aim of achieving export-led growth. Since the country aspires to stimulate growth of both labor and goods export; the key question is how these two flows are inter-related. In other words, it is imperative to ascertain the impact of labor emigration on the export of manufactures. Hence, we intend to investigate whether labor export promotes or hurts export of goods. Although such notion has been investigated from the perspective of export and immigration; research evidence is by far very rare on the relationship between export and emigration.

Wong (1995) notes that factor movements beyond borders are significant and can exert profound effects not only on countries' bilateral trade in goods but also on their economic welfare. Though not unanimous, it is apparent that there are significant interactions between trade and factor mobility. However, international trade theories lack consensus, as to whether the goods and labor flows are substitutes or complements (Mundra, 2005). Standard neo-classical trade theory treats trade and migration as substitutes. Mundell (1957) postulates that international trade in goods and factor mobility is substitutes because more of one leads to less of the other. Growth in 
international trade lowers the potential mobility of factors, while a rise in international mobility of factors reduces the volume of trade between countries.

The assertions that international trade and factor mobility are substitutes derive from Paul Samuelson's advancement of the Factor-Price-Equalization theorem which states that international trade brings about equalization in earnings for homogenous factors across nations which is corollary to Heckscher-Ohlin trade theory. The logic behind this idea is that as long as relative factor prices differ between countries, same happens to commodity prices, and trade continues to rise. Therefore, international trade continues to expand until relative commodity prices and relative factor prices are exactly equal between countries. This intuition is corollary to the $\mathrm{H}-\mathrm{O}$ theorem of trade and is commonly referred to as $\mathrm{H}-\mathrm{O}-\mathrm{S}$ theorem which holds only of assumptions of the $\mathrm{H}-\mathrm{O}$ theorem, as such perfect competition in all commodity and factor markets and constant returns to scale. The essence of the H-O-S theorem is that trade acts as substitutes for the international mobility of factors of production in its effect on factor prices. With perfect mobility, labor would migrate from low wage nation to the high wage nation and capital would move from the low-return to the high-return nation (Salvatore, 2010). Hence, from the Heckscher-Ohlin perspective, trade and factor flows are substitutes when the countries involved possess dissimilar factor endowments. On the contrary, trade and factor flows between countries with similar factor endowments but dissimilar technologies are complements.

Thus, international migration is driven by differences in both factor endowments and technologies across countries, and trade theory does not provide unanimous picture of whether trade and immigration act as substitutes or complements (Mundra, 2005). In order overcome theoretical contradictions, empirical researches were relied on. Nonetheless, empirical research mostly evidenced the relationship between immigration and trade of host countries. Considering lack of literature on linkage between emigration and trade, we devised this study that employs the gravity model of trade to empirically examine the impact of emigrants' stock on the export flows from Bangladesh. It is worth mentioning that Bangladesh not only constitutes a major source of international labor supply; the country profoundly relies on inward remittances for dealing with macroeconomic shocks. Thus, this research aims to minimize the gap of existing literature by incorporating the supply side perspective; and deliver important policy implications for the developing countries that appear to be major sources of manpower supply.

The rest of the paper is structured as follows: Section 2 reviews empirical literature; Section 3 provides empirical model of this research along with operational definition of the underlying variables; Section 4 explains data and methodology; Section 5 reports results and discussion; and the last section gives conclusion and policy implications.

\subsection{Literature review and research hypothesis}

The realm of globalization consists of a number of pillars, including international trade, international migration, and international investment (Roy and Berg, 2006) and, these three components are growing much more rapidly than output (Kugler and Rapoport, 2011). As a result of the rapid rise in international labor flows, research on migration related aspects drew immense attention. Empirics on international migration can be grouped into three streams of analyses: (1) determinants of international labor migration (Borjas, 1987; Clark et al. 2007; Karemera et al. 2000; Kim and Cohen, 2010; Lewer and Berg, 2008; Mayda, 2007; Pedersen et al. 2008; Zavodny, 1999); (2) relationship between international trade and immigration (Gould, 1994; Co et al. 2004; Dunlevy and Hutchinson, 1999; Girma and Yu, 2002; Hatzigeorgiou, 2010; Lewer and Berg, 2009; Mundra, 2005); and (3) migration and development linkage (Emmanuel et al. 2009; Olesen, 2002).

Wong (1995) argues that international labor migration is a very special type of factor movement because it involves not just the movement of the factor but also the movement of the factor of owners. Flows of labor internationally cause a change in the quantity and quality composition of factor supplies in the source and destination countries. Thus, movement of labor augments production and demand in the receiving country, while creates the opposite impact on the sending country. Immigrants also influence international trade flows across countries because they bring a preference for their home country products that foster bilateral trade between home and host economies. Furthermore, immigrants form a network in the host country and lower the transaction cost with host country, thereby, facilitates bilateral trade. But the very fundamental question of whether labor migration and trade acts as complements or substitutes remains unsettled in the theoretical domain. The empirical evidences in this regard are provided in the following.

Pioneering studies by Gould (1994) and Dunlevy and Hutchinson (1999) indicate a positive link between trade flows and immigration in the USA. In recent studies, Co et al. (2004) and Mundra (2005) also document a strong pro-trade effect of immigration in the USA, with state level data and country level data, respectively. Co et al. 
(2004) explore the export effect of immigration using state level exports to 28 immigrant source countries for a single year, while Mundra (2005) examines the effects of immigration on both components of international trade-export and imports. The later study undertakes a semi-parametric approach with the dynamic fixed effects estimation technique which shows that inbound labor migration and US's trade flows act as complements. Immigration effect on imports is positive for all goods (finished and intermediate) but the effect on exports is positive only for finished goods. "The findings supports the hypothesis that for finished goods where country specific information is crucial for trading, immigrants have a pro-trade effect for both US imports and US exports'(Mundra 2005, p.65).

Head and Ries (1998) examine the trade and migration link in the case of Canada using the host country's trade with 136 partners from year 1980 to 1992. The same study uncovers a positive relationship between Canadian trade flows and international migration to this country. The gravity type analysis reveals that a 10 percent rise in immigrants contributes to one percent increase in export flows from Canada to the immigrants' home country and three percent increase in imports to the former from the latter.

Girma and Yu (2002) explore the relationship between immigration and trade using UK data and show that the impact on trade differ depending on whether immigrants come from commonwealth or non-commonwealth countries. Specifically, it finds that immigration from non-commonwealth countries have a positive significant effect on exports from and imports to the UK. While looking on the commonwealth countries, it finds no significant export impact and a reduction of imports. Thus, immigrants from the commonwealth countries appear to substitute imports to the UK.

Lewer and Berg (2009) present the findings on trade and immigration link from the group of OECD countries. They study 10 year panel data of bilateral trade among 16 OECD countries and a large set of immigrant source countries and find a result supportive to the hypothesis that trade and immigration link in the OECD countries is complementary. Their findings establish that immigration influences trade positively through a number of channels as such creating trade networks between immigrants' sending and receiving countries, and raising income in the home countries.

The available empirical literature mostly unveils a pro-trade link between trade and migration from the perspective of advanced countries that receive immigrants and thus clearly signal a dearth of literature from the home country perspective. Under this backdrop, we develop the following hypothesis for empirical testing:

Hypothesis: Export of manufactures from Bangladesh stimulates export of manpower and thus these two flows act as complements.

\subsection{Model specification}

In order to assess the link between emigration and export flows, a gravity type specification with panel data is employed. Many authors including Head and Ries (1998), Dunlevy and Hutchinson (1999), Rauch and Trindade (2002), Co et al. (2004), Lewer and Berg (2009) applied the gravity model of trade for exploring linkage between trade and immigration. In line with the gravity model of trade, we specify the equation.

$$
\begin{aligned}
& \ln \left(E X_{i j t}\right)= \beta_{0}+\beta_{1} \ln \left(G D P_{i t}\right)+\beta_{2} \ln \left(G D P_{j t}\right)+\beta_{3} \ln \left(R G D P P C_{i j t}\right) \\
&+\beta_{4} \ln \left(D I S T_{i j}\right)+\beta_{5} \ln \left(R E R_{i j t}\right)+\beta_{6} \ln \left(M S T O C K_{i j t}\right)+\varepsilon_{i j t} \\
& j=1, \ldots, n \quad t=1, \ldots, T
\end{aligned}
$$

In equation, In denotes natural logarithm, $i$ indicates the exporting country which is Bangladesh in the current analysis, $j=1, \ldots, n$ stands for the cross-section and $t=1, \ldots, T$ implies the time period. The dependent variable $\mathrm{EX}_{i j t}$ stands for export flows from Bangladesh to country $j$ at time $t$.

- $\mathrm{GDP}_{\mathrm{it}}$ and $\mathrm{GDP}_{\mathrm{jt}}$ (Gross domestic product of exporter and importer): The GDP of the exporter (GDPit) is the measure of supply of exports, while the importer's GDP ( $\left.G D P_{j t}\right)$ is the measure of demand for imports. Exports from a country increase with its own GDP growth and imports to a country increase with the growth of its own GDP. Therefore, $\beta_{1}$ and $\beta_{2}$ are expected to have positive effects on bilateral trade flows. In this study, GDP data is measured at nominal US \$.

- $R G D P C_{i j t}$ (Country js GDP per capita relative to is GDP per capita): This variable can have a positive or negative sign. A positive sign indicates that export from Bangladesh mainly flows to the countries having high income difference with the former and export pattern falls with inter-industry type, while a negative sign implies that export patterns fits with intra-industry type. 
- $\quad$ DIST $_{\mathrm{ij}}$ (Distance): In the gravity model, distance is commonly used as the proxy of transportation costs. Transportation costs have both direct and indirect effects on international trade flows. The direct effects of transportation costs on trade flows come in the form a change in the price of the traded commodity between nations, while indirect influence is exerted through the firm's international location decision. The higher the costs of transportation including freight charges, insurance charges, cost of loading and unloading; the lower will be the volume of bilateral trade. That means, a homogeneous good will be traded internationally only if the pre-trade price difference between two countries exceeds the costs of transporting the good from one nation to the other (Salvatore, 2010). Since transportation costs are inversely related to trade flows, the distance variable should have a negative sign.

- RER $_{i j t}$ (Bilateral real exchange rates): Bilateral nominal exchange rate can be defined as unit(s) of home currency (currency of the exporting country) to a unit of foreign currency (currency of the importing country). When nominal exchange rate is adjusted with the foreign to domestic price ratio, it becomes the bilateral real exchange rate. The process of finding the bilateral real exchange rates is as follows:

$$
R E R_{i j}=N E R_{i j / \$} \frac{C P I_{j}}{C P I_{i}}
$$

where RER denotes real exchange rate; NER stands for nominal exchange rates in US \$; CPI indicates consumer price index; $i$ and $j$ means exporter and importer, respectively. A rise (fall) in the bilateral exchange rate indicates depreciation (appreciation) of exporter's currency. Depreciation of an exporter's currency stimulates export flows due to decline in relative price levels. Hence, it should have a positive sign.

- $\quad M S T O C K_{i j t}$ measures the export effects of the stock of Bangladesh's emigrants in country $j$. A positive sign of $\beta_{6}$ indicates complementarity between export and emigration, while a negative sign implies that these flows act as substitutes. Stock data were not available for the GCC countries for some years and are generated by the authors. In doing so, emigration stock in year $t$ have been calculated by summing the annual number of emigrants to country $j$ during five consecutive years in the past and deducting the number of emigrants entering into the same destination in year $t$ - 6 . The assumption of this calculation process was that the workers emigrate to the GCC countries for contract job and have to return to home after certain period of time, five years in this case, since the host countries do not allow life time settlement.

\subsection{Data and methodology}

\subsection{Data sources}

Empirical analysis deals with export flows?both labor and goods? from Bangladesh to 20 destinations ${ }^{1}$ during the period of 1995-2010. The destination countries have been limited to those that are the major recipients of immigrants from Bangladesh. Ironically, these sample countries also constitute Bangladesh's major export partners and they shared over 67 percent of Bangladesh's total export of goods in the year 2010. We obtained bilateral exports data in current US (\$) from the IMF's Direction of Trade Statistics (CD-ROM). Consumer price index, GDP and GDP per capita data came from WDI (CD-ROM) while bilateral nominal exchange rates in US\$ were collected from the UNCTAD. Distance data were generated from the CEPII's distance data set. Data on labor emigration were accumulated from numerous sources as such Citizenship and Immigration Statistics of Canada, Australian Department of Immigration and Citizenship, International Labor Organization (ILO), Migration Information Organization, National Statistical Institute of Italy, World Bank's Global Migration Database.

\subsection{Methodology}

As empirical tools, we employ random effects (RE) and fixed effects (FE). Post estimation tests indicate the presence of serial correlation as well as cross-sectional dependence.

(i) Wooldridge test of autocorrelation:

$\mathrm{H}_{0}$ : No first order autocorrelation.

$\mathrm{F}=10.32, \mathrm{P}>\mathrm{F}=0.00$. Hence, the null of no autocorrelation in the panel is rejected.

(ii) Pesaran's test of cross-sectional dependence:

$\mathrm{H}_{0}$ : There is no cross-sectional dependence (CD).

$\mathrm{CD}=29.81, \mathrm{P}=0.00$. Thus, the null of cross-sectional independence is rejected.

Due to the presence of serial correlation and cross-sectional dependence in the series, RE and FE with AR(1) is

\footnotetext{
1 The export partners of Bangladesh included Australia, Bahrain, Brunei Darussalam, Canada, Germany, Italy, Republic of Korea, Kuwait, Malaysia, Netherlands, Norway, Oman, Qatar, Saudi Arabia, Singapore, Spain, Sweden, United Arab Emirates, United Kingdom, and United States.
} 
applied and estimation results are reported in Table 1. Both estimation techniques show proper sign and significance at the same level, i.e., at a $1 \%$ level of significance. As usual, the fixed effects model reports slightly lower magnitude of coefficients due to the control of unobserved fixed effects. Although, both RE and FE report closely similar findings, Hausman test has been conducted in order to select the appropriate one. The Hausman test shows a value of $\mathrm{Chi}=3.16$ with $\mathrm{P}=0.68$ and thus, $\mathrm{RE}$ model is appropriate over the FE. However, this choice causes no difference in the analysis of linkage between emigration and export since both regressions reveal exactly the same level of coefficient with the same level of significance. One reason for no variation in the two alternative estimation methods is that all the variables included in the regression are in the bilateral ( $i$ and $j$ ) form. In the presence of variables that are unilaterally related to either $i$ or $j$, FE shows more consistent result as suggested by Feenstra (2002).

\subsection{Results and discussion}

This study finds theoretically and empirically consistent results relating to the conventional determinants of goods exports as such GDP, difference between GDP per capita of export and import country, geographic distance, and real exchange rate. More specifically, $\beta_{1}$ and $\beta_{2}$ indicate that GDP of the export and import country have significant positive effects on export flows. Thus, capacity expansion of the exporter and income growth of the importer are important determinants of bilateral trade. RGDPC reports a positive sign indicating that export from Bangladesh mainly flows to those countries that have high income difference with the former and export pattern fits with inter-industry type. Geographic distance between countries also constitutes an important determinant of export. Higher distance exerts negative effect on export since transportation cost rises with a distant trade partner. Real exchange rate was found to have positive impact on export which means depreciation of the exporter's currency stimulates export flows due to a decline in relative price levels.

\begin{tabular}{|c|c|c|}
\hline \multicolumn{3}{|c|}{ Table 1: RE and FE with AR (1) correction } \\
\hline VARIABLES & $\mathrm{RE}$ & FE \\
\hline $\mathrm{GDP}_{j}$ & $\begin{array}{l}1.38^{* * *} \\
(0.000)\end{array}$ & $\begin{array}{l}1.34^{* * *} \\
(0.000)\end{array}$ \\
\hline $\mathrm{GDP}_{\mathrm{i}}$ & $\begin{array}{l}1.13^{* * *} \\
(0.000)\end{array}$ & - \\
\hline RGDPPC & $\begin{array}{l}0.40^{* * *} \\
(0.000)\end{array}$ & $\begin{array}{l}0.37^{* * *} \\
(0.000)\end{array}$ \\
\hline DIST & $\begin{array}{l}-0.99 * * * \\
(0.000)\end{array}$ & $\begin{array}{l}-0.70^{* * *} \\
(0.000)\end{array}$ \\
\hline RER & $\begin{array}{l}0.29^{* * *} \\
(0.000)\end{array}$ & $\begin{array}{l}0.28^{* * *} \\
(0.000)\end{array}$ \\
\hline MSTOCK & $\begin{array}{l}-0.14^{* * *} \\
(0.000)\end{array}$ & $\begin{array}{l}-0.14^{* * *} \\
(0.000)\end{array}$ \\
\hline CONSTANT & $\begin{array}{l}-39.46^{* * *} \\
(0.000)\end{array}$ & $\begin{array}{l}-12.69^{* * *} \\
(0.000)\end{array}$ \\
\hline $\mathrm{R}^{2}$ & 0.91 & 0.92 \\
\hline Wald Chi & 2941 & - \\
\hline $\mathrm{F}$ & - & 616 \\
\hline Observations & 318 & 302 \\
\hline Number of year & 16 & 16 \\
\hline Number of cross section & 20 & 20 \\
\hline
\end{tabular}

They key finding of the empirical exercise here is that stock of emigrants significantly lower exports from Bangladesh. In other words, a higher stock of manpower substitutes Bangladesh's exports in the immigrants receiving countries. The estimated coefficient of emigrant stock variable (MSTOCK) indicates that a one percent increase in the stock of emigrants reduces exports by 0.14 percent. That means, export falls about one percent by a 10 percent rise in emigrants stock in the destination country. Thus, we reject the hypothesis of complementary relationship between goods and manpower exports from Bangladesh to the rest of the world. Our results contradict with Co et al. (2004), Dunlevy and Hutchinson (1999), Gould, 1994, Head and Ries (1998), Lewer and Berg (2009) and Mundra, 2005 who investigated linkage between export of goods from and migration to advanced countries. Such contrasted results signify that effects of labor migration on goods export from home and host countries are different. The cause of such variation can also be attributed to the type of manufacturing exports. In essence, manpower exports from a country will substitute its export of labor intensive manufactures. Our findings further document that both labor and goods export from Bangladesh do not flow to the same high income 
economies even though high income of destination countries have positive effect on both of these flows. In fact, Bangladesh's major export partners are the high income OECD countries, whereas the GCC countries are the prime locations for labor emigration.

\subsection{Conclusion and policy implications}

The gravity model analysis of relationship between export of goods and labor from Bangladesh to 20 major trade partners demonstrates that these two flows function as substitutes to one another. As a result of substituting relationship, higher growth of one will reduce the growth of the other in the same location. Our results sharply contradict with empirical literature. Such dissimilar empirics carry a number of connotations as such (i) impact of labor migration on the home and host country's export of goods may be different; (ii) the nature of relationship between manpower and goods export depends on the skill level of manpower and labor vs. capital intensity of goods; (iii) labor and goods from Bangladesh move to two distinct types of destinations. Thus, economic policy to stimulate export of goods and manpower must give cognizance to this intrinsic relationship between them.

The policy implications of this finding is that high income countries in the West will continue to serve as export markets for Bangladesh's manufactured goods, while the Gulf countries will remain as the key locations for emigration, at least under the current pattern of labor intensive manufactures and export of unskilled manpower. Economic policy as well as foreign policy in Bangladesh must address this inherent relationship between export and labor flows since emigration of unskilled labor largely depends on bilateral diplomatic relations whereas export patterns depend on comparative cost advantage. Furthermore, expansion of domestic production capacity and employment generation must be facilitated in the country to foster pro-trade oriented long-run economic development. This objective can be put in action by proper channeling of remittances in the short to midterm. However, a long term tendency of high growth in labor outflows and growing dependence of Bangladesh's economy on remittance receipts will depress role of export as an engine of growth. Apart from minimizing the gap in existing literature and making policy related contributions, the authors generated emigration stock data for Bangladesh by accessing to numerous sources.

\section{References}

Borjas, J.G. (1987) Self-selection and the Earnings of Immigrants, American Economic Review, 77(4), 531-553.

Clark, X., Timothy, J., J.G. Williamson (2007) Explaining U.S. Immigration, 1971-1998, The Review of Economics and Statistics, 89(2):359-373. http://dx.doi.org/10.1162/rest.89.2.359

Co, C.Y., Euzent, P., Martin, T. (2004) The Export Effect of Immigration into the US. Applied Economics, 36(6): 573583. http://dx.doi.org/10.1080/0003684042000217616

Dunlevy, J.A., Hutchinson, W.K. (1999) The Impact of Immigration on American Import Trade in the Late Nineteenth Centuries. Journal of Economic History, 59(4):1043-1062. http://dx.doi.org/10.1017/S002205070002413X

Emmanuel, L., Mark, P., Francisco, R., Mathew, C. (2009) Revisiting the Migration-Development Nexus: A Gravity Model Approach, Human Development Research Paper 2009/44, UNDP. http://mpra.ub.unimuenchen.de/19227/ (Accessed: 10 January 2012).

Feenstra, R.C. (2002) Border Effects and the Gravity Equation: Consistent Methods for Estimation, Scottish Journal of Political Economy, 49(5):491-506. http://dx.doi.org/10.1111/1467-9485.00244

Girma, S., Yu, Z. (2002) The Link between Immigration and Trade: Evidence from the United Kingdom. Review of World Economics, 138(1): 115-130. http://dx.doi.org/10.1007/bf02707326

Girma, S., Yu, Z. (2002) The Link between Immigration and Trade: Evidence from the United Kingdom. Review of World Economics, 138(1): 115-130. http://dx.doi.org/10.1007/bf02707326

Gould, D. (1994) Immigration Links to the Home Country: Empirical Implications for US Bilateral Trade Flow. The Review of Economics and Statistics, 76(2):302-316. http://dx.doi.org/10.2307/2109884

Hatzigeorgiou, A. (2010) Migration as Trade Facilitation: Assessing the Links between International Trade and Migration. The B.E. Journal of Economic Analysis \& Policy, 10(1): 1-33. http://dx.doi.org/10.2202/19351682.2100

Hatzigeorgiou, A. (2010) Migration as Trade Facilitation: Assessing the Links between International Trade and Migration. The B.E. Journal of Economic Analysis \& Policy, 10(1): 1-33. http://dx.doi.org/10.2202/19351682.2100

Head, K., Ries, J. (1998) Immigration and Trade Creation: Econometric Evidence from Canada. Canadian Journal of Economics, 31(1): 47-62. http://dx.doi.org/10.2307/136376

Karemera, D., Oguledo, V.I., Davis, B. (2000) A Gravity Model Analysis of International Migration to North America, Applied Economics, 32(13):1745-1755. http://dx.doi.org/10.1080/000368400421093 
Kim, K., Cohen, J.E. (2010) Determinants of International Migration Flows to and from Industrialized Countries: A panel Data Approach beyond Gravity, International Migration Review, 44(4):899-932. http://dx.doi.org/10.1111/j.1747-7379.2010.00830.x

Kugler, M., Rapoport, H. (2011) Migration, FDI, and the Margins of Trade. Center for International Development at Harvard University, Working Paper No. 222.

Lewer J.J. and Berg, H. Van den (2008) A Gravity Model of Immigration, Economic Letters, 99(1):164-167. http://dx.doi.org/10.1016/j.econlet.2007.06.019

Mayda, A.M. (2007) International Migration: A Panel Data Analysis of the Determinants of Bilateral Flows, Center for Research and Analysis of Migration, Discussion Paper No. 07/07. http://eprints.ucl.ac.uk/14276/1/14276.pdf (Accessed: 4 May 2012).

Mundell, R.A. (1957) International Trade and Factor Mobility. The American Economic Review, 47(3):321-335.

Mundra, K. (2005) Immigration and International Trade: A Semiparametric Empirical Investigation. Journal of International Trade and Economic Development, 14(1):65-91. http://dx.doi.org/10.1080/0963819042000333252

Olesen, H. (2002) Migration, Return and Development: An Institutional Perspective. International Migration, 40(5):125-150. http://dx.doi.org/10.1111/1468-2435.00214

Pedersen, P.J., Pytlikova, M., Smith, N. (2008) Selection and Network Effects-Migration flows into OECD Countries, European Economic Review, 52(7):1160-1186. http://dx.doi.org/10.1016/j.euroecorev.2007.12.002

Rauch, J.E., Trindade, V. (2002) Ethnic Chinese Networks in International Trade. The Review of Economics and Statistics, 84 (1):116-130. http://dx.doi.org/10.1162/003465302317331955

Roy, A.G., Berg, H. (2006) Foreign Direct Investment and Economic Growth: A Time Series Approach. Global Economy Journal, 6(1):1-19.

Salvatore, D. (2010) Introduction to International Economics. Second Edition, USA: John Wiley and Sons.

Wong, K. (1995) International Trade in Goods and Factor Mobility. The MIT Press: Massachusetts, USA.

World Bank (2011) Migration and Remittances Fact Book 2011, 2nd Edition, Washington: USA.

Zavodny, M. (1999) Determinants of Recent Immigrants' Locational Choices, The International Migration Review, 33(4):1014-1030. http://dx.doi.org/10.2307/2547361 